\title{
LEGITIEME PORTIE DALAM HUKUM WARIS ISLAM DI INDONESIA
}

\author{
Shintiya Dwi Puspita \\ email: syntyaa@gmail.com \\ Fabian Fadhly \\ email: fabianfadhly@ymail.com
}

\begin{abstract}
Indonesia recognizes three different inheritance system based respectively on the Civil Code, Islamic law and adat law. This article discusses the regulation concerning legitieme portie, the absolute right of the successor (heirs) which by law cannot be disregarded by the benefactor. The question here is whether legitieme portie, expressly regulated in the western inheritance law may also be found in the Islamic inheritance system? The second question concerns the possibility of - within the Islamic inheritance system - through the application of the legitieme portie - to deny the wife and/or parents' right to the inheritance. This research argues that the Islamic inheritance system contains rules which cannot be disregarded by the benefactor and at the same time guarantee the wife's right to the inheritance left by the benefactor.
\end{abstract}

Keywords:

legitieme portie, Islamic inheritance law

\begin{abstract}
Abstrak
Indonesia mengakui keberlakuan tiga sistem kewarisan: hukum waris adat, hukum waris Islam dan hukum waris berdasarkan hukum perdata barat. Satu hal penting yang ditelaah tulisan ini adalah tentang pengaturan legitieme portie, hak ahli waris yang tidak dapat dikurangi oleh pewaris. Pertanyaannya adalah apakah legitieme portie yang diatur di dalam hukum perdata barat juga dikenal dalam sistem waris berdasarkan hukum Islam? Pertanyaan kedua adalah peniadaan hak waris istri dan/atau orang tua pewaris berdasarkan legitieme portie juga dapat dilakukan berdasarkan sistem waris hukum Islam. Penelitian yang dilakukan menunjukkan bahwa sistem waris hukum Islam mengenal pengaturan hak ahli waris berdasarkan hukum yang tidak dapat begitu saja disimpangi oleh pewaris, namun tetap menjamin hak isteri sebagai ahli waris.
\end{abstract}

Kata kunci: legitieme portie, hukum waris Islam.

\section{Pendahuluan}

Perkembangan hukum Indonesia tidak dapat dilepaskan dari sejarah yang menyertainya. Sejarah tersebut menunjukkan bagaimana Indonesia mengenal tiga sistem hukum, ${ }^{1}$ dimana sistem satu sama lain memberikan pengaruh, sesuai dengan kemampuannya beradaptasi dengan masyarakat Indonesia yang beragam

1 Sistem hukum adat, Sistem hukum barat dan sistem hukum Islam. 
suku, bahasa, budaya dan lain sebagainya. Salah satunya adalah bidang hukum waris yang mendapat pengaruh dari hukum Islam dan hukum barat. Pengaruh ini memiliki dampak besar terhadap hubungan manusia dengan manusia lainnya, terutama dalam hubungan hukum antara anggota keluarga dalam penyelesaian sengketa waris. Sengketa waris dapat muncul manakala terdapat ketiadaan atau ketidakjelasan aturan dalam menyelesaikan permasalahan waris. Sengketa tersebut tidak hanya dapat menimbulkan pertengkaran, bahkan sampai kepada tindakan saling membunuh antara para ahli waris. Pertanyaan yang muncul pada setiap terjadi peristiwa kematian seseorang, adalah "Bagaimana harta peninggalannya (jika ada) harus dibagikan kepada yang berhak menerimanya dan kepada siapa saja harta itu dipindahkan, serta bagaimana caranya. Semua ini harus diatur dalam hukum kewarisan".2

Hukum waris Islam bertujuan mengatur cara-cara pembagian harta peninggalan agar dapat bermanfaat kepada ahli waris secara adil dan baik. Tujuan ini memiliki makna bahwa harta peninggalan atau harta pusaka adalah hak milik dari pewaris yang didapat melalui usahanya sendiri maupun didapatkan oleh dirinya sebagai ahli waris secara sah dan dibenarkan oleh agama, dan begitu pula dengan ahli waris diperbolehkan untuk mendapatkan harta peninggalan melalui cara yang sah dan dibenarkan pula. ${ }^{3}$ Tujuan ini menunjukkan fungsi hukum Islam sebagai ajaran kebenaran yang mengarahkan manusia untuk berbuat sesuai dengan tuntunan Allah SWT dan Nabi Muhammad Saw. Fungsi tersebut berupa fungsi ibadah, fungsi amar ma'ruf nahi munkar, fungsi zawajir, dan fungsi tanzim wa islah al-ummah. ${ }^{4}$ Tujuan ini, dalam hukum waris, diterjemahkan dalam lima

${ }^{2}$ Kamaruddin, Beragam Norma Hukum Dalam Penerapan Waris, Jurnal Al-Risalah, Volume 13 Nomor 1 Mei 2013, hlm. 22.

${ }^{3}$ Tamakarin, Asas-Asas Hukum Waris menurut Tiga Sistim Hukum, Pionir, Bandung, 1987, hlm. 84.

${ }^{4}$ Amrullah Ahmad, dkk, Dimensi Hukum Islam dalam Sistem Hukum Nasional, Gema Insani Press, Jakarta, 1996, hlm. 89-92. Fungsi Ibadah berkaitan dengan hukum Islam adalah ajaran Tuhan yang harus dipatuhi umat manusia, dan kepatuhannya merupakan ibadah sekaligus juga merupakan indikasi keimanan seseorang. Fungsi amar ma'ruf nahi munkar berkaitan dengan perlindungan terhadap manusia sebagai mukallaf serta sebagai fungsi kontrol sosial terhadap hal-hal yang dilarang oleh Allah SWT dan Nabi Muhammad Saw demi terwujudnya maqashid syariah, yaitu mendatangkan (menemukan) kemaslahatan dan menghindarkan dari kemudaratan 
sistem kewarisan yaitu ijbari, bilateral, individual, keadilan, berimbang dan peritiwa kematian. ${ }^{5}$

Keadaan ini berbanding terbalik dengan sistem kewarisan dalam hukum perdata $(B W)$ yang menganut sistem individual. Prinsipnya sistem ini menyatakan bahwa harta waris harus dibagikan kepemilikannya di antara para ahli waris yang ada dan sah. Individualitas ini dapat dilihat dari pengakuan eigendom yang bersifat perorangan dan telah ditetapkan berdasarkan undang-undang ( $a b$ intestaat) atau melalui pewarisan terhadap ahli waris menurut wasiat (testamentair erfrecht). ${ }^{6}$ Ketentuan ini dapat dilihat dari makna Pasal 584 BW:

"Bahwa pewarisan merupakan salah satu cara yang secara limitatif (membatasi) dalam penentuan terhadap hak milik dan karena benda (hak) milik merupakan salah satu unsur pokok daripada benda, argumentasi ini menyebabkan hukum waris diatur dalam Buku II bersamaan dengan pengaturan benda yang lain."7

Eman Suparman mempertegas pandangan ini bahwa:

"Menurut konsepsi hukum perdata Barat, hukum waris merupakan bagian dari hukum harta kekayaan, oleh karena itu hanyalah hak kewajiban yang berwujud harta kekayaan yang merupakan warisan dan diwariskan". 8

Contoh sifat individual ditunjukkan oleh KUHPerdata dengan menempatkan anak laki-laki maupun anak perempuan yang mempunyai kedudukan sebagai ahli waris legitieme portie. Kedua kata ini memberikan hak mutlak terhadap ahli waris tertentu, dengan mendapatkan jaminan dari undang-undang apabila pada saat

(jalbu al-masalih wa daf'u al mafasid). Kemaslahatan dan kemudaratan di sini mencakup di dunia dan akhirat. Fungsi zawajir, berkaitan dengan sanksi hukum sebagai pemaksa untuk melindungi waraga masyarakat dari segala bentuk ancaman serta perbuatan yang membahayakan. Seperti sanksi bagi pembunuhan yang dihukum dengan qishash-diyat dan hudud bagi pelaku zina. Fungsi tanzim wa islah al-ummah berkenaan dengan sarana yng mengatur dan memperlancar proses interaksi sosial sehingga terwujudlah masyarakat yang harmonis, aman dan sejahtera (baldatun thoyyibatun wa rabbun ghafur).

5 A. Sukris Saramadi, Transendensi Keadilan Hukum Waris Islam Transformatif, Rajawali Pers, Jakarta, 1997, hlm. 19.

${ }^{6}$ H.F.A. Vollmar, Pengantar Studi Hukum Perdata, (terj. I. S. Adiwimarta), Rajawali Pers, Jakarta, 1983, hlm. 374.

7 J. Satrio, Hukum Waris, Alumni Bandung, 1992, hlm. 1.

8 Eman Suparman, Intisari Hukum Waris Indonesia, Mandar Maju, Bandung, 1998, hlm. 21. 
tertentu berkeinginan untuk menuntut pembagian harta waris. ${ }^{9}$ Hak mutlak diartikan sebagai hak milik yang tidak dapat digugat keabsahannya oleh apa dan siapapun, serta dapat dipertahankan oleh pemiliknya. Hak mutlak tersebut dibagi dalam: hak pribadi, misalnya hak atas nama baik; hak kekeluargaan, misalnya hak yang dimiliki orang tua terhadap anaknya, atau sebagai wali atau karena perkawinan; hak kebendaan, yaitu hak atas suatu benda karena hak milik atau karena menguasai suatu surat berharaga, misalnya suatu cek, wesel, saham dan lain sebagainya; dan hak atas benda tidak berwujud (immaterieele rechten), misalnya hak atas merek, octrooi, hak cipta. ${ }^{10}$

Asser Meyers menyatakan tujuan undang-undang menetapkan legitieme portie adalah untuk menghindari dan melindungi anak sebagai ahli waris dari kecenderungan pewaris menguntungkan orang lain. ${ }^{11}$ Dengan kata lain tujuan dari adanya lembaga hukum ini adalah agar harta peninggalan sebagai harta keluarga tetap berada di dalam keluarga. Ketentuan ini secara tidak langsung dimaknai sebagai fungsi pemerataan di antara ahli waris, sebab dengan ketentuan legitieme portie tidak mungkin adanya pewarisan mayoraat. ${ }^{12}$ Legitieme portie berarti suami atau isteri tidak memiliki hak yang sama dengan anak, walaupun telah dipersamakan layaknya anak. Peraturan mengenai legitieme portie oleh undang-undang dipandang sebagai pembatasan kemerdekaan seseorang untuk membuat wasiat atau testament menurut kehendaknya sendiri. ${ }^{13}$

Ahli waris dalam ruang lingkup legitieme portie yang berhak menerima hak waris adalah ahli waris dalam garis lurus, baik itu ke atas maupun ke bawah, tegasnya hak akan timbul apabila terdapat seseorang dalam suatu keadaan

\footnotetext{
${ }^{9}$ Benyamin Asri, Thabrani Asri, Dasar-Dasar Hukum Waris Barat (Suatu Pembahasan Teoritis dan Praktek), Tarsito, Bandung, 1988, hlm. 5.

10 R. Soerjatin, Beberapa Soal Pokok Hukum Perdata dan Hukum Dagang, Pradnya Paramita, Jakarta, 1978, hlm. 10.

11 Oemar Salim, Dasar-Dasar Hukum Waris Di Indonesia, Rineka Cipta, Jakarta, 1991, hlm. 90.

12 Sistem kewarisan mayoraat diartikan sebagai keadaan yang memberikan hak tunggal untuk mendapatkan seluruh harta waris atau berhak tunggal untuk mewarisi sejumlah harat pokok dari suatu keluarga. (Werdono Soewardi, Hukum Waris di Daerah Teluk Yos Sudarso, Prandya Paramita, Jakarta, 1979, hlm. 19).

13 R. Subekti, Pokok-Pokok Hukum Perdata, Intermasa, Jakarta, 1998, hlm. 114 dan 115.
} 
sungguh-sungguh tampil ke muka sebagai ahli waris menurut undang-undang. ${ }^{14}$ Legitieme portie di satu sisi memiliki persamaan dengan waris dalam sistem Islam yaitu: "memberikan hak pada anak laki-laki maupun perempuan, di sisi lain menghalangi isteri maupun suami untuk mendapatkan haknya, walaupun dapat diberikan melalui wasiat. Hal ini berbeda dengan aturan Islam bahwa isteri/suami berhak mendapatkan haknya, karena merupakan golongan ashabul furudh (golongan yang telah ditentukan mendapatkan hak waris berdasarkan kepada ketentuan syara')."

\section{Hukum Waris Islam di Indonesia}

Hukum kewarisan Islam yang secara mendasar merupakan ekspresi langsung dari teks-teks suci yang telah disepakati keberadaannya, berada dalam ranah hukum kekeluargaan, sebagaimana diatur dalam al-Quran Surat an-Nissa. ${ }^{15}$ Ini adalah manifestasi dari rangkaian teks dokumen suci dan merupakan prinsip fundamental dalam ajaran Islam. Suatu fakta yang tak dapat dipungkiri bahwa kelahirannya ditunjukkan melalui teks-teks yang rinci, sistematis, konkrit, dan realitis, dan tidak hanya untuk merespon permasalahan hukum pada zaman kemunculannya, melainkan juga sebagai kontruksi ajaran keagamaan. Sisi ini dapat dibuktikan dengan melalui paparan ide dasar sistem kewarisan Islam yang sesungguhnya tanpa adanya berbagai penafsiran. ${ }^{16}$

Hukum Kewarisan Islam adalah suatu sistem hukum yang norma dasarnya dibentuk sesuai sumbernya al-Qur'an dan al-Hadits. Kedua sumber hukum tersebut, secara khusus menunjuk ketentuan-ketentuan tentang hukum kewarisan. Peran serta cendekiawan muslim terdahulu, dalam mengolah kedua sumber hukum tersebut untuk dikonstruksikan secara sitematis melalui ijtihad dengan cara/metode (manhaj) tertentu, sehingga terbentuklah ajaran hukum-

\footnotetext{
14 Surini Ahlan, Intisari Hukum Waris Menurut Burgelijk Wetboek, Ghalia Indonesia, Jakarta, 1982, hlm. 21.

15 Agus Sudaryanto, Aspek Ontologi Pembagian Waris Dalam Hukum Islam Dan Hukum Adat Jawa, Jurnal Mimbar Hukum, Volume 22, Nomor 3, Oktober 2010, hlm. 536.

16 Anonim.
} 
hukum kewarisan (Fiqh al-Mawarits) yang berlaku bagi orang-orang Islam di dunia Arab pada khususnya dan di dunia Islam pada umumnya.

Masuknya Kerajaan Belanda mengubah tataran hukum waris Islam di Indonesia melalui teori receptie, yaitu bahwa hukum yang berlaku dalam realita masyarakat adalah hukum adat, sedangkan hukum Islam dapat diberlakukan apabila telah beradaptasi dengan hukum adat. Teori ini dikemukakan oleh Christian Snouck Hurgronje (1857-1936). Kemudian teori ini didukung oleh Cornelis Van Vollenhoven (1874-1933), Bertrand Ter Haar, dan beberapa muridnya. ${ }^{17}$

Perubahan yang dilakukan oleh C. Snouck Hurgronje ditujukan pada tiga prinsip utama pelaksanaan hukum Islam di Indonesia: pertama, ritual keagamaan atau aspek ibadah dalam Islam, dimana rakyat Indonesia harus dibiarkan bebas menjalankannya. Alasannya adalah untuk memberikan keyakinan dalam pikiran masyarakat bahwa pemerintah Kerajaan Belanda tidak melakukan intervensi terhadap keimanan mereka. ${ }^{18}$

Kedua, berkaitan dengan lembaga-lembaga sosial Islam, aspek muamalat, perkawinan, waris, wakaf, dan hubungan sosial lainnya. Pemerintah harus berupaya mempertahankan dan menghormati keberadaannya.

\footnotetext{
17 Abdul Manan, Masalah Hukum Perdata Islam di Indonesia, Kencana, Jakarta, 2006, hlm. 11. Perkembangan ini lahir tidak serta merta melainkan melalui perjalanan yang panjang, dipengaruhi oleh berbagai macam latar belakang. Pengaruh tersebut dimulai dengan berkembangnya pendapat pakar hukum Belanda Lodewijk Willem Christian van den Berg melalui teorinya receptie in complexu yang mengandung makna untuk menerima ajaran agama secara menyeluruh. Teori ini memiliki maksud bila seseorang telah memeluk agama Islam, maka dia akan menjalankan semua ajarannya termasuk kewarisan. (A. Basiq Djalil, Peradilan Agama Di Indonesia, Prenadia Group, Jakarta, 2006, hlm. 49). Klaim provokatif dan distorsif ini sangat berpengaruh terhada eksistensi hukum Islam ketika itu, bahkan hingga sekarang ini, sampaisampai Hazairin menyebutnya sebagai teori "iblis". (Ahmad Rafiq, Pembaharuan Hukum Islam di Indonesia, Gama Widya, Yogyakarta, 2001, hlm. 68)).

${ }^{18}$ Kebebasan dan keleluasaan yang diberikan oleh pemerintah Belanda dikarenakan keyakinan merupakan wilayah yang peka bagi kaum muslim serta menyentuh nilai-nilai keagamaan mereka yang paling dalam. Tujuan dari prinsip pertama ini dimaksudkan untuk merebut hati banyak penganut agama Islam, sehingga mengurangi pengaruh perlawanan "kaum muslim fanatik" terhadap pemerintah Belanda. (Alwi Shihab, Membendung Arus: Respons Gerakan Muhammadiyah Terhadap Penetrasi Misi Kristen di Indonesia, Mizan, Bandung, 1998, hlm. 86).
} 
Ketiga, berkenaan dengan politik pemerintah Belanda yang berusaha untuk mencegah masyarakat Islam Indonesia menyebarkan seruan-seruan pan Islamisme, sehingga dapat memunculkan perlawanan politik atau bersenjata menentang pemerintahan Belanda. Pemangkasan gagasan ini ditujukan untuk memperkecil pengaruh Islam dalam ranah politik, karena ketakutan akan kebangkitan Islam yang dipelopori oleh Jamaluddin al-Afghani dan Muhammad Abduh dan dapat mempengaruhi kesadaran umat Islam Indonesia. ${ }^{19}$ Teori ini menempatkan hukum adat sebagai sistem yang diterapkan dan bekerja dalam masyarakat, sedangkan hukum Islam dianggap hanya sebagai sistem yang bersifat teoritis, walaupun pada kenyataannya mayoritas masyarakat adat tersebut beragama Islam. ${ }^{20}$ Implikasi lain yang muncul karena berkembangnya teori receptie adalah dengan dibentuknya lembaga peradilan oleh pemerintah Kerajaan Belanda yang memiliki kewenangan absolut dan relatif yang berbeda.

Asas personalitas menunjukkan begitu pentingnya umat Islam diberikan arahan dalam bentuk aturan hukum untuk tetap berada dalam pengakuan keIslamannya melalui proses yang dibenarkan baik itu secara syar'i, maupun melalui legalitas. Patut dipahami bahwa Islam meletakkan dasar pewarisan berdasarkan hal-hal sebagai berikut: pertama, asas ijbari (imperatif) yaitu peralihan harta dari pewaris kepada ahli waris berlaku dengan sendirinya tanpa tergantung kepada

\footnotetext{
${ }^{19}$ Amir Nuruddin, Azhari Akmal Tarigan, Hukum Perdata Islam di Indonesia Studi Kritis dari Fikih, UU No. 1/1974 sampai KHI, Kencana, Jakarta, 2004, hlm. 12-13.

${ }^{20}$ Ratno Lukito, Islamic Law And Adat Encounter The Experience Of Indonesia, A Thesis submitted to the Faculty of Graduate Studies and Research in partial fulfillment of the requirements for the degree of Master of Arts in Islamic Studies Institute of Islamic Studies McGill University Montreal, Canada, 1997, pg. 65, (unpublished). Keterangan lebih lanjut dinyatakan oleh Ratno Lukito bahwa: baik hukum adat maupun hukum Islam tidak dapat dipisahkan satu dengan yang lainnya, dikarenakan sessungguhnya adat dan Islam adalah satu sistem bukan dua sistem yang bertolak belakang. Snouck Hurgronje telah gagal untuk mengenali fakta dua sistem hukum tersebut dalam kehidupan masyarakat adat tidak dapat dipisahkan. Politik Belanda yang memisahkan penyelesaian sengketa menjadi kewenangan Peradilan Agama apabila berkaitan dengan hukum keluarga Islam, dengan ketentuan sengketa tersebut tidak mengenai hukum kepemilikan dikarenakan hal tersebut merupakan ranah hukum adat bertolak belakang dengan fakta. Fakta menunjukkan bahwa bagi penduduk asli (masyarakat adat) hukum Islam menjadi bagian dari hukum adat. Contohnya, dalam ruang lingkup perkawinan yang dilandasi oleh hukum Islam, tidak dapat dipisahkan dari mengenai kepemilikan yang lahir dari perkawinannya tersebut.
} 
kehendak keduanya. Asas ijbari dalam hukum kewarisan Islam tidak dalam arti yang memberatkan ahli waris. Contohnya pewaris mempunyai hutang yang lebih besar dari warisan yang ditinggalkannya, kewajiban ahli waris hanya membayar utang sebesar warisan yang ditinggalkan oleh pewaris. ${ }^{21}$

Kedua, asas bilateral yaitu seseorang berhak menerima waris dari kedua garis keturunan yaitu patrineal dan matrineal. Seorang laki-laki berhak mendapatkan waris dari ayah dan ibunya, begitu pula dengan wanita berhak untuk memperoleh waris dari keduanya. ${ }^{22}$

Ketiga, asas 'ubudiyah berkaitan dengan pembagian waris secara hukum Islam yang merupakan bagian dari ibadah kepada Allah SWT, akan mendapatkan pahala bila ditaati layaknya mentaati pelaksanaan hukum-hukum Islam lainnya. Ketentuan demikian dapat kita lihat dalam surat an-Nisa' ayat 11 dan 12, kemudian dikunci dengan ayat 13 dan $14 .^{23}$

Keempat, kematian berkaitan dengan peralihan harta dari pewaris kepada ahli waris, dengan ketentuan telah terjadinya kematian baik itu kematian haqiqi, diartikan dengan hilangnya nyawa seseorang (yang semula nyawa itu berwujud padanya). Contohnya tatkala seseorang disaksikan meninggal, atau dengan melalui pembuktian, yakni kesaksian dua orang yang adil atas kematian seseorang. Kematian hukmiy adalah, suatu kematian yang disebabkan oleh putusan hakim, seperti bila hakim memutuskan kematian terhadap seseorang yang tidak diketahui kabar beritanya, tidak diketahui tempat tinggalnya, dan tidak

\footnotetext{
21Pasnelyza Karani, Tinjauan Ahli Waris Pengganti Dalam Hukum Kewarisan Islam Dan Hukum Kewarisan KUHPerdata, Tesis pada Program Pascasarjana Magister Kenotariatan Universitas Diponegoro, Semarang 2006, hlm. 42, (tidak dipublikasikan). Mukti Arto dalam bukunya Hukum Waris Bilateral Dalam Kompilasi Hukum Islam halaman 32, mengatakan asas ini berkaitan dengan ketaatan seseorang terhadap ketentuan yang ditetapkan melalui al-Qur'an dan al-Hadits Nabi Muhammad Saw dalam bidang hukum waris, dikarenakan hukum waris memiliki memiliki sifat 'ubudiyah dan menjadi ukuran ketakwaan. Ketentuan ini disandarkan kepada perintah Allah SWT dalam surat an-Nisaa ayat 49, menegaskan kewajiban untuk menaati perintah (hukumhukum) Allah SWT, Rasulullah Saw, dan ulil amri dari umat Islam itu sendiri.

22 Muhammad Daud Ali, Hukum Islam, Rajawali Pers, Jakarta, 2001, hlm. 127.

${ }^{23}$ Anonim.
} 
pula diketahui hidup atau matinya. Kematian taqdiriy diartikan sebagai suatu kematian disandarkan kepada dugaan yang kuat. ${ }^{24}$

Kelima, asas kekerabatan yang ditujukan terhadap keluarga (kerabat) terdekat pewaris, seperti suami, isteri, orang tua, anak, saudara laki-laki, paman dan saudara dari garis keturunan ibu/dzawil arham (ketentuan ini berlaku bila disandarkan kepada fiqih Imam Abu Hanifah dan Imam Ahmad ibn Hambal). ${ }^{25}$

Mintarno menyatakan ${ }^{26}$ bahwa perbedaan gender tidak menentukan hak kewarisan dalam Islam. Artinya laki-laki dan perempuan mempunyai hak yang sama kuatnya untuk mendapatkan waris. Hal ini secara jelas disebut dalam alQur'an yang menyamakan kedudukan laki-laki dan perempuan dalam hak mendapatkan warisan. ${ }^{27}$ Secara rinci diterangkan kesamaan kekuatan hak menerima warisan antara anak laki-laki, dan anak perempuan, ${ }^{28}$ ayah dan ibu, ${ }^{29}$ suami dan istri, ${ }^{30}$ saudara laki-laki dan perempuan. ${ }^{31}$

Asas kekerabatan yang menjadi salah satu pedoman penentuan pewarisan menempatkan isteri atau suami tidak dapat dihalangi perolehan warisannya sekalipun oleh anak. Sebabnya adalah keduanya termasuk ke dalam ashab al-furud atau kelompok yang mendapatkan prioritas utama dalam sistem waris Islam. ${ }^{32}$ Besar kecilnya bagian warisan setiap kerabat adalah berdasarkan derajat kekerabatan mereka. Karena itu, kerabat-kerabat yang lebih kuat mendapatkan bagian yang lebih banyak. Bahkan tidak semua kerabat akan mendapatkan

\footnotetext{
${ }^{24}$ Komite Fakultas Syariah Universitas Al-Azhar, Hukum Waris (terj. Addy Aldizar, Fathurrahman), Senayan Abadi Publishing, Jakarta, 2011, hlm. 29-30.

25 Mohd Ridzuan Awang, The Islamic Inheritance Law (Faraid): The Manifestation of Comprehensive Inheritance Management In Islam, working paper was presented at the National Convention of Faraid and Hibah 2008, organised by the Islamic Development Malaysia Department (JAKIM) at the Multipurpose Hall of the Federal Territory Mosque, Kuala Lumpur on 7 August 2008, hlm. 10.

${ }^{26}$ Mintarno. Hukum Waris Islam Dipandang dari Persepektif Hukum Berkeadilan Gender (studi Di Kecamatan Mranggen Kabupaten Demak), pada Program Pascasarjana Magister Kenotariatan Universitas Diponegoro, Semarang 2006, hlm. 64, (tidak dipublikasikan)

${ }^{27}$ Surah an-Nisa ayat 7

${ }^{28}$ Surah an-Nisa ayat 11-12, 176.

${ }^{29}$ Surah an-Nisa ayat 11.

${ }^{30}$ Surah an-Nisa ayat 12.

${ }^{31}$ Surah an-Nisa ayat 12 dan 176.

32 Id.
} 
warisan, karena hak-hak yang dimiliki oleh sebagian kerabat akan timbul jika terdapat kerabat tertentu. Hal ini telah diatur secara jelas dalam al-Quran dan asSunnah. ${ }^{33}$

Ahli waris yang dapat terhijab penuh adalah seluruh ahli waris kecuali anak, ayah, ibu, dan suami atau isteri. Kelima ahli waris ini tidak akan pernah terhijab secara penuh. Anak laki-laki dan ayah dapat menutup ahli waris lain secara hijab penuh sedangkan suami-isteri tidak pernah menghijab siapapun di antara ahli waris. $^{34}$ Bahkan anak yang masih dalam kandunganpun diperhitungkan haknya. Kesemuanya itu mendapat bagian sesuai dengan syaratsyarat yang digariskan Al-Qur'an dan Hadist. Dengan perkataan lain, hukum waris Islam lebih condong untuk membagi harta warisan kepada sebanyak mungkin ahli waris yang sederajat, dengan menentukan bagian-bagian tertentu kepada beberapa ahli waris. Misalnya apabila ahli waris terdiri dari ayah, ibu, suami (duda) atau isteri (janda) dan anak-anak, mereka semua berhak atas harta warisan. ${ }^{35}$

Asas Keadilan Berimbang merupakan fondasi lain. Asas ini menempatkan baik laki-laki maupun perempuan pada kedudukan yang sama untuk tampil sebagai ahli waris, mewarisi harta peninggalan yang ditinggalkan oleh pewaris. Asas ini mengandung pengertian bahwa senantiasa terdapat keseimbangan antara hak dan kewajiban, antara hak yang diperoleh seseorang dengan kewajiban yang harus ditunaikan. Laki-laki dan perempuan mendapat hak yang sebanding dengan kewajiban yang dipikulnya masing-masing kelak dalam kehidupan keluarga dan masyarakat. ${ }^{36}$ Tanggung jawab tersebut merupakan kewajiban yang harus dilaksanakan, terlepas dari persoalan apakah isteri mampu atau tidak, anak-anak

${ }^{33}$ Nur Mohamad Kasim, Studi Komparatif Waris Menurut Hukum Islam Dan Hukum Adat, Research Paper, hlm. 6.

34 Amir Syarifuddin, Hukum Kewarisan Islam, Kencana, Padang, 2004, hlm. 201. Hijab adalah terhalangnya seseorang ahli waris untuk menerima warisan, disebabkan adanya ahli waris (kelompok ahli waris) yang lebih utama daripadanya. (Suhrawardi K.Lubis dan Komis Simanjuntak, Hukum Waris Islam, Sinar Grafika, Jakarta, 1995, hlm.59).

35 Kamaruddin, Beragam Norma Hukum Dalam Penerapan Waris, Jurnal Al-Risalah Volume 13 Nomor 1 Mei 2013, hlm. 32.

36 Muhammad Daud Ali, supra, hlm. 285. 
memerlukan bantuan atau tidak. Berdasarkan keseimbangan antara hak yang diperoleh dan kewajiban yang harus ditunaikan, sesungguhnya apa yang diperoleh seseorang laki-laki dan seorang perempuan dari harta warisan manfaatnya akan sama mereka rasakan. ${ }^{37}$ Termasuk dalam pengertian ini adalah bayi yang masih berada dalam kandungan. Meskipun masih berupa janin, apabila dapat dipastikan hidup, melalui gerakan (kontraksi) atau cara lainnya, maka bagi si janin tersebut mendapatkan harta warisan. ${ }^{38}$ Untuk itu perlu diketahui batasan yang tegas mengenai batasan paling sedikit (batas minimal) atau paling lama (batas maksimal) usia kandungan. Ini dimaksudkan untuk mengetahui kepada siapa janin tersebut akan dinasabkan. ${ }^{39}$

Kedua asas ini menunjukkan pengaturan tentang hak-hak dan kewajibankewajiban yang harus ditaati dan diikuti oleh setiap muslim. Pelanggaran atas hak orang lain atau kelalaian dalam melaksanakan kewajiban akan memunculkan persoalan atau permasalahan baru. Hal itu tentu tidak sejalan dengan tujuan Hukum Islam, yaitu mewujudkan kemaslahatan umum dan memberikan kemanfaatan, dan menghindarkan dari kerusakan bagi umat manusia. ${ }^{40}$

\section{Legitieme Portie}

Legitieme portie (wettelijk erfdeel), secara harafiah diterjemahkan sebagai warisan menurut Undang-Undang, praktisi hukum mengenalnya sebagai bagian mutlak. Bagian mutlak adalah bagian dari warisan yang diberikan undang-undang kepada ahli waris dalam garis lurus ke bawah dan ke atas. Bagian mutlak ini tidak boleh di tetapkan atau dicabut dengan cara apapun oleh pewaris, baik melalui cara hibah yang diberikan semasa pewaris hidup maupun dengan surat wasiat melalui hibah wasiat (legaat dan erfstelling). ${ }^{41}$ Pelanggaran terhadap ketentuan ini

\footnotetext{
${ }^{37}$ Chatib Rasyid, Azas-Azas Hukum Waris Dalam Islam, Research Paper, hlm. 8.

38 Sayyid Sabiq, Fiqih Sunnah, Pena Pundi Aksara, Jakarta Selatan, 2006, hlm. 483.

39 Zainuddin Ali, Pelaksanaan Hukum Waris Di Indonesia, Sinar Grafika, Jakarta, 2008, hlm. 29.

40 Anonim

41 Andreas Prasetyo Senoadji, Penerapan Legitieme Portie Portie (Bagian Mutlak) Dalam Pembagian Waris Menurut Kitab Undang-Undang Hukum Perdata Studi Kasus Putusan
} 
memberikan pemilik hak untuk menuntut agar hak yang dijamin oleh undangundang tersebut di laksanakan sebagaimana mestinya. Ketentuan mengenai bagian mutlak ini diatur dalam KUHPerdata Pasal 913-Pasal 916 a. ${ }^{42}$ Legitieme portie dianggap sebagai hak-hak yang diakui secara hukum (statutoris) atau berdasarkan undang-undang (statuta), dan hak-hak statutoris lainnya yang muncul kemudian. Hak-hak statutoris lainnya memberikan perlindungan pada pasangan dan anak-anak. Mereka akan menerima setidaknya jumlah minimum tertentu dari harta peninggalan. Hak-hak itu berfungsi sebagai jaring pengaman: "Para pembuat undang-undang ingin agar beberapa individu terlindungi dan terjamin dengan baik, bahkan sekalipun orang-orang ini tidak berhak atau hanya berhak untuk memperoleh harta warisan dalam jumlah yang sedikit berdasarkan wasiat." 43

Ketentuan ini tidak saja diberlakukan dalam BW, melainkan pula lazimnya terhadap hukum perdata yang dipengaruhi oleh sistem hukum Eropa Kontinental, seperti Code Civil Filipina, dan Code Civil Perancis. Ketentuan tentang Legitieme portie bersifat perseorangan dalam ranah perlindungan hukum, dan pelaksanaan ketentuan tersebut diserahkan kepada tiap-tiap ahli waris. ${ }^{44}$ Legitieme portie merupakan ketentuan yang mengandung unsur paksaan dalam hukum waris perdata, misalnya ketentuan pemberian hak mutlak (Legitieme portie) kepada ahli waris tertentu terhadap jumlah tertentu dari harta waris, atau ketentuan yang melarang pewaris membuat suatu ketetapan seperti menghibahkan bagian tertentu dari harta warisnya. Dalam hal ini penerima hibah mempunyai kewajiban

Mahkamah Agung Reg No. 148/PK/Perd/1982, Tesis pada Program Pascasarjana Magister Kenotariatan Universitas Diponegoro, Semarang, 2007, hlm. 38. (tidak dipublikasikan).

42 Nani Suwondo, Kedudukan Wanita Indonesia dalam Hukum dan Masyarakat, Ghalia Indonesia, Jakarta, 1981, hlm. 113.

43 Hans H.M. ter Haar, dkk, Hukum Waris, dalam Hukum Tentang Orang, Hukum Keluarga Dan Hukum Waris Di Belanda Dan Indonesia, Pustaka Larasan Denpasar atas kerjasama antara Universitas Indonesia, Universitas Leiden dan Universitas Groningen, 2012, hlm. 89.

44 R. Subekti, Perbandingan Hukum Perdata, Pradnya Paramita, Jakarta, 1993, hlm. 23. Code Civil Perancis memakai istilah portion de biens disponible yang diartikan sebagai bagian harta yang secara bebas dapat diberikan, sedangkan di Belanda mengenalnya dengan istilah beschikbare deel meskipun peraturan perundang-undangannya tidak memakai istilah itu untuk menunjukkan padanan kata dari legitieme portie. 
untuk mengembalikan harta yang telah dihibahkan kepadanya ke dalam harta waris guna memenuhi bagian mutlak (legitieme portie) ahli waris tersebut. ${ }^{45}$ Aturan ini memaksa pembagian waris dilakukan menurut cara yang diatur dan diperbolehkan berdasarkan KUHPerdata. Penyimpangan akan aturan ini dikategorikan atau termasuk ke dalam pelanggaran.

Pengakuan terhadap peralihan hak dalam kategori legitieme portie hanya dapat timbul apabila sesorang dalam suatu keadaan yang sebenarnya tampil sebagai ahli waris menurut undang-undang. Contohnya pewaris telah meninggal dunia memiliki anak atau cucu, maka orang tua dari pewaris, tidak diakui sebagai ahli waris dan tidak berhak pula atas suatu legitieme portie. Penerima hak Legitieme portie dinamakan legitimaris. Dirinya dapat meminta pembatalan wasiat (testament) yang melanggar haknya tersebut serta memiliki hak untuk meminta pengurangan (inkorting) terhadap semua pemberian waris, baik berupa erfstelling (pengangkatan waris) maupun yang berupa legaat (hibah wasiat) dan semua pemberian berbentuk schenking yang mengurangi haknya.46 Ketentuan ini menempatkan orang tua pewaris bukan sebagai bagian keluarga pewaris. Sebagaimana diketahui bahwa lahirnya seseorang dipengaruhi oleh adanya ikatan antara seorang laki-laki dengan seorang wanita, peran mereka berdualah yang menyebabkan dapat lahirnya seorang anak. Artinya menjadi hal yang membingungkan bila kelahiran anak atau cucu dapat menghilangkan kedudukan orang tua sebagai ahli waris. Pasal 832 KUHPerdata memiliki pandangan yang

${ }^{45}$ Anisitus Amanat, Membagi Warisan Berdasarkan Pasal-Pasal Hukum Perdata BW, Rajawali Pers. Jakarta, 2001, hlm. 1.

46 R. Subekti, Pokok-Pokok Hukum Perdata, Intermasa, Jakarta, 1954, hlm. 93-94. Kelahiran seorang anak merupakan sebuah peristiwa hukum yang menimbulkan banyak akibat hukum, antara lain dari peristiwa kelahiran dapat menimbulkan hubungan waris, hubungan keluarga, hubungan perwalian dan hubungan-hubungan lainnya yang berkaitan dengan lahirnya subyek hukum baru ke dunia dengan segala status dan kedudukannya di mata hukum. Dalam hukum waris, kelahiran anak merupakan peristiwa hadirnya ahli waris yang akan menduduki peringkat tertinggi dalam pewarisan. Menurut hukum keluarga, kelahiran seorang anak akan menjadi awal dari timbulnya hak dan kewajiban alimentasi orang tua kepada anaknya. Sedangkan dalam hal perwalian, akan timbul hak dan kewajiban pada saat orang tua si anak tidak sanggup memikul tanggung jawab terhadap anaknya. (Anik Tri Haryani, Tiara Oliviarizky Toersina, Hak Mewaris Anak Luar Kawin Menurut Hukum Waris BW (Burgerlijk Wetboek) Pasca Putusan Mahkamah Konstitusi Nomor 46/PUU-VIII/2010, Jurnal Sosial, Volume 14 Nomor 1 Maret 2013, hlm. 4. 
sama. Bila kita memperhatikan ketentuan pasal tersebut, ahli waris ialah para keluarga sedarah dan isteri yang masih hidup dan jika ini semua tidak ada, maka yang berhak menjadi ahli waris adalah negara. ${ }^{47}$

Konsep ini menunjukkan bahwa pewarisan mulai terhitung sejak meninggalnya pewaris. Sejak saat itu hak dan kewajibannya akan beralih kepada para penerima waris. Berdasarkan ketentuan Pasal 834 KUHPerdata, penerima waris berhak menguasai kekayaan pewaris (boedel) berlandaskan pada haknya sebagai penerima waris dari pewaris. Pengakuan ini serupa dengan pengakuan bahwa berdasarkan hak tersebut ahli waris dapat mempertahankan haknya dari siapapun juga (ahli waris lainnya) yang memiliki pengakuan yang sama. ${ }^{48}$ Walaupun dalam pelaksanaan hukum waris perdata, ahli waris berdasarkan surat wasiat yang lebih diutamakan, dengan pengecualian selama isi dan pembagian dalam surat wasiat tidak bertentangan dengan undang-undang. Pertimbangan hukumnya karena surat wasiat merupakan kehendak terakhir dari pewaris terhadap harta warisnya, dengan ketentuan tidak boleh merugikan ahli waris yang memiliki bagian mutlak (legitieme portie). Hal mana diatur dalam Pasal 913 KUHPerdata. ${ }^{49}$ Bagian mutlak, diperuntukkan bagi legitimaris secara bersamasama, bila seorang legitimaris menolak (verwerp) atau tidak patut mewarisi (onwaardig), sehingga bagiannya menjadi tidak dapat dikuasai (werd niet

${ }^{47}$ Nur Hidayati, Tinjauan Yuridis Tentang Hak Janda Dalam Pembagian Warisan Menurut Hukum Adat Jawa (Studi Kasus di Pengadilan Negeri Sukoharjo), Skripsi pada Fakultas Hukum Universitas Sebelas Maret, Surakarta, 2008, hlm. 26, (tidak dipublikasikan). Keluarga sedarah yang berhak mewaris adalah: Anak atau keturunannya dan isteri yang masih hidup (Golongan I); Orang tua (bapak dan ibu) dan saudara pewaris (Golongan II); Nenek dan kakek, atau leluhur lainnya dalam garis lurus ke atas (Pasal 853 KUHPerdata) (Golongan III); dan anak keluarga dalam garis ke samping sampai tingkat ke enam (Pasal 861 ayat 1) (Golongan IV).

48 Suharnoko, Dampak Pewarisan Dan Likuidasi Harta Kekayaan, dalam Hukum Tentang Orang, Hukum Keluarga Dan Hukum Waris Di Belanda Dan Indonesia, diterbitkan oleh Pustaka Larasan Denpasar atas kerjasama antara Universitas Indonesia, Universitas Leiden dan Universitas Groningen, 2012, hlm. 148. Subekti menjelaskan bahwa hak untuk mempertahankan tersebut ditujukan terhadap orang-orang lain yang memiliki klaim serupa (ahli waris lainnya) bukan pada orang yang menguasai kebendaan (harta benda) milik pewaris di bawah hubungan hukum yang sah dengan pewaris, misalnya berlandaskan hubungan sewa-menyewa. Ketentuan Pasal 1318 KUHPerdata menetapkan bahwa perjanjian akan mengikat tidak saja pihak-pihak yang membuatnya, namun juga pada para ahli waris mereka. Dengan demikian, perjanjian mengikat sebagai hukum juga pada ahli waris selama perjanjian tersebut masih berlaku.

${ }^{49}$ Andreas Prasetyo Senoadji, Supra, hlm. 46. 
beschikbaar). Bagian itu akan diterima oleh legitimaris lain. Bagian mutlak tetap diperuntukkan bagi mereka, jika legitimaris menuntutnya, sedangkan jika legitimaris itu tidak menuntutnya, maka pewaris masih mempunyai beschikkings recht atas seluruh hartanya. ${ }^{50}$

Kecakapan bertindak merupakan syarat bagi berlakunya ketentuan ini, sebagaimana diatur dalam pasal 330 alinea 1 KUHPerdata, yaitu harus belum mencapai usia duapuluh satu tahun dan juga harus belum menikah. Berdasarkan argumentum a contrario, dapat ditafsirkan jika salah satu syarat minderjarig tidak terpenuhi, secara langsung dapat dikatakan manusia tersebut termasuk kriteria meerderjarig. Kecakapan dalam KUHPerdata termasuk ke dalam kriteria biologis, sehingga setiap orang akan memperoleh kecakapan pada saat yang sama, yaitu pada saat seseorang telah mencapai usia dua puluh satu tahun atau telah menikah. ${ }^{51}$

Keadaan ini menunjukkan bahwa suatu pewarisan dalam legitieme portie disandarkan pada kecakapan secara biologis legitimaris, yaitu dengan merujuk kepada kemampuannya untuk melangsungkan pernikahan, atau dengan kata lain dapat dinyatakan telah mampu untuk bertanggungjawab dalam suatu perkawinan. Ketentuan ini tidak hanya ditujukan kepada laki-laki saja, melainkan kepada wanita juga. Karena kemampuan biologis laki-laki cenderung lebih lambat dibandingkan wanita, walaupun keduanya secara hukum memiliki kedudukan yang setara dan sama sebagai subjek hukum yang cakap.

Ketentuan waris lahir adalah upaya untuk memberikan perlindungan bagi pewaris, ahli waris, maupun harta yang menjadi objek pewarisan, baik itu berasal (berdasarkan) sistem waris Islam, sistem hukum perdata barat maupun sistem hukum adat. Dengan kata lain aturan waris telah menetapkan berbagai macam hak dan kewajiban yang dilekatkan kepada ketiga hal di atas. Ahli waris tidak akan

${ }^{50}$ Hartono Soerjopratiknjo. Hukum Waris Testamenter, Seksi Notariat Fakultas Hukum Universitas Gajah Mada, Yogyakarta, 1984, hlm. 109, (tidak dipublikasikan).

51 Sulastriyono, Hukum Keluarga Dan Harta Perkawinan Adat, dalam Hukum Tentang Orang, Hukum Keluarga Dan Hukum Waris Di Belanda Dan Indonesia, diterbitkan oleh Pustaka Larasan Denpasar atas kerjasama antara Universitas Indonesia, Universitas Leiden dan Universitas Groningen, 2012, hlm. 167-168. 
mendapatkan harta waris bila pewaris tidak memiliki objek waris untuk dibagi dan diberikan sesuai dengan hak yang seharusnya diterima oleh ahli waris.

Islam mengatur dengan tegas melalui al-Quran dan as-Sunnah perihal ketentuan serta bagian yang harus diterima oleh setiap ahli waris berdasarkan asas ijbari (imperatif), asas bilateral, asas 'ubudiyah, asas kematian dan asas kekerabatan. Kesemuanya melalui asas keadilan dan berimbang, karena setiap ahli waris akan mendapatkan haknya sesuai dengan kewajiban yang terdapat dalam dirinya. Islam mengatur satu ahli waris tidak dapat menghilangkan hak ahli waris lainnya degan cara yang tidak dibenarkan oleh syara' atau melanggar keenam asas di atas. Keadaan ini pada satu sisi diikuti oleh sistem waris perdata barat dengan pengaturan bahwa ahli waris mendapatkan apa yang menjadi haknya, akan tetapi disisi lain terdapat ketentuan yang membolehkan kerabat ahli waris tidak mendapatkan waris.

Ketentuan itu direpresentasikan dalam konsep legitieme portie. Konsep ini mengakibatkan orang tua maupun isteri atau suami tidak diperkenankan mendapat harta waris, karena secara mutlak hak tersebut jatuh kepada anak dari pewaris. Patut dipahami bahwa orang tua maupun isteri atau suami seharusnya mendapatkan bagian dari harta waris. Argumentasinya adalah tidak mungkin anak pewaris akan mendapatkan bagian haknya tanpa ada ketiga subjek waris tersebut. Orang tua pewaris berperan sebagai asal dari munculnya anak pewaris, begitu pula dengan isteri atau suaminya, karena tidak mungkin akan lahir anak pewaris tanpa kehadiran ketiganya.

Ketentuan lain yang kontradiktif dalam konsep legitieme portie adalah bahwa waris perdata barat hanya dapat diberikan kepada ahli waris bila telah dianggap cakap atau telah mampu melangsung pernikahan atau mampu bertangungjawab dalam suatu ikatan keluarga yang membagi peran, tugas maupun fungsi dari suami isteri itu sendiri dalam kehidupan berumah tangga. Waris Islam tidak mengenal persyaratan pembagian waris ditentukan oleh cakap atau tidaknya subjek hukum atau dikenal dengan taklif (mumayyiz/baligh). Bayi 
yang masih berada dalam kandungan dan dianggap hidup tetap mendapatkan bagian dari haknya, dengan ketentuan ketika dilahirkan dalam keadaan hidup.

\section{Penutup}

Hukum waris Islam di Indonesia didasarkan pada asas keadilan dan berimbang dan terkandung di dalamnya ijbari (imperatif), bilateral, 'ubudiyah, kematian dan asas kekerabatan. Pembagian waris tidak dapat lepas dari aspek tersebut. Isteri dan/atau suami maupun orang tua pewaris tidak dapat dihilangkan haknya kecuali bila dibenarkan oleh Syara'. Waris perdata barat membenarkan penghilangan hak ketiganya berdasarkan kepada aturan tentang legitieme portie yang terikat dengan cakap atau tidaknya legitimaris untuk memperoleh bagiannya.

\section{Daftar Pustaka}

\section{Buku}

A. Basiq Djalil, Peradilan Agama Di Indonesia, Prenadia Group, Jakarta, 2006.

A. Sukris Saramadi, Transendensi Keadilan Hukum Waris Islam Transformatif, Rajawali Pers, Jakarta, 1997.

Abdul Manan, Masalah Hukum Perdata Islam di Indonesia, Kencana, Jakarta, 2006. Ahmad Rafiq, Pembaharuan Hukum Islam di Indonesia, Gama Widya, Yogyakarta, 2001.

Alwi Shihab, Membendung Arus: Respons Gerakan Muhammadiyah Terhadap Penetrasi Misi Kristen di Indonesia, Mizan, Bandung, $1998 .$.

Amir Nuruddin, Azhari Akmal Tarigan, Hukum Perdata Islam di Indonesia Studi Kritis dari Fikih, UU No. 1/1974 sampai KHI, Kencana, Jakarta, 2004.

Amir Syarifuddin, Hukum Kewarisan Islam, Kencana, Padang, 2004.

Amrullah Ahmad, dkk, Dimensi Hukum Islam dalam Sistem Hukum Nasional, Gema Insani Press, Jakarta, 1996.

Anisitus Amanat, Membagi Warisan Berdasarkan Pasal-Pasal Hukum Perdata BW, Rajawali Pers. Jakarta, 2001.

Benyamin Asri, Thabrani Asri, Dasar-Dasar Hukum Waris Barat (Suatu Pembahasan Teoritis dan Praktek), Tarsito, Bandung, 1988.

Eman Suparman, Intisari Hukum Waris Indonesia, Mandar Maju, Bandung, 1998.

H.F.A. Vollmar, Pengantar Studi Hukum Perdata, (terj. I. S. Adiwimarta), Rajawali Pers, Jakarta, 1983. 
Hans H.M. ter Haar, dkk, Hukum Waris, dalam Hukum Tentang Orang, Hukum Keluarga Dan Hukum Waris Di Belanda Dan Indonesia, Pustaka Larasan Denpasar atas kerjasama antara Universitas Indonesia, Universitas Leiden dan Universitas Groningen, 2012.

J. Satrio, Hukum Waris, Alumni Bandung, 1992.

Komite Fakultas Syariah Universitas Al-Azhar, Hukum Waris (terj. Addy Aldizar, Fathurrahman), Senayan Abadi Publishing, Jakarta, 2011.

Muhammad Daud Ali, Hukum Islam, Rajawali Pers, Jakarta, 2001.

Nani Suwondo, Kedudukan Wanita Indonesia dalam Hukum dan Masyarakat, Ghalia Indonesia, Jakarta, 1981.

Oemar Salim, Dasar-Dasar Hukum Waris Di Indonesia, Rineka Cipta, Jakarta, 1991.

R. Soerjatin, Beberapa Soal Pokok Hukum Perdata dan Hukum Dagang, Pradnya Paramita, Jakarta, 1978.

R. Subekti, Pokok-Pokok Hukum Perdata, Intermasa, Jakarta, 1954.

----------, Perbandingan Hukum Perdata, Pradnya Paramita, Jakarta, 1993.

------, Pokok-Pokok Hukum Perdata, Intermasa, Jakarta, 1998.

Sayyid Sabiq, Fiqih Sunnah, Pena Pundi Aksara, Jakarta Selatan, 2006.

Suhrawardi K.Lubis dan Komis Simanjuntak, Hukum Waris Islam, Sinar Grafika, Jakarta, 1995.

Suharnoko, Dampak Pewarisan Dan Likuidasi Harta Kekayaan, dalam Hukum Tentang Orang, Hukum Keluarga Dan Hukum Waris Di Belanda Dan Indonesia, diterbitkan oleh Pustaka Larasan Denpasar atas kerjasama antara Universitas Indonesia, Universitas Leiden dan Universitas Groningen, 2012.

Sulastriyono, Hukum Keluarga Dan Harta Perkawinan Adat, dalam Hukum Tentang Orang, Hukum Keluarga Dan Hukum Waris Di Belanda Dan Indonesia, diterbitkan oleh Pustaka Larasan Denpasar atas kerjasama antara Universitas Indonesia, Universitas Leiden dan Universitas Groningen, 2012.

Surini Ahlan, Intisari Hukum Waris Menurut Burgelijk Wetboek, Ghalia Indonesia, Jakarta, 1982.

Tamakarin, Asas-Asas Hukum Waris menurut Tiga Sistim Hukum, Pionir, Bandung, 1987.

Werdono Soewardi, Hukum Waris di Daerah Teluk Yos Sudarso, Prandya Paramita, Jakarta, 1979.

Zainuddin Ali, Pelaksanaan Hukum Waris Di Indonesia, Sinar Grafika, Jakarta, 2008.

\section{Jurnal}

Agus Sudaryanto, Aspek Ontologi Pembagian Waris Dalam Hukum Islam Dan Hukum Adat Jawa, Jurnal Mimbar Hukum, Volume 22, Nomor 3, Oktober 2010.

Anik Tri Haryani, Tiara Oliviarizky Toersina, Hak Mewaris Anak Luar Kawin Menurut Hukum Waris Bw (Burgerlijk Wetboek) Pasca Putusan Mahkamah Konstitusi Nomor 46/PUU-VIII/2010, Jurnal Sosial, Volume 14 Nomor 1 Maret 2013. 
Kamaruddin, Beragam Norma Hukum Dalam Penerapan Waris, Jurnal Al-Risalah, Volume 13 Nomor 1 Mei 2013.

\section{Skripsi, Tesis}

Andreas Prasetyo Senoadji, Penerapan Legitieme Portie Portie (Bagian Mutlak) Dalam Pembagian Waris Menurut Kitab Undang-Undang Hukum Perdata Studi Kasus Putusan Mahkamah Agung Reg No. 148/PK/Perd/1982, Tesis pada Program Pascasarjana Magister Kenotariatan Universitas Diponegoro, Semarang, 2007.

Mintarno. Hukum Waris Islam Dipandang dari Persepektif Hukum Berkeadilan Gender ( studi Di Kecamatan Mranggen Kabupaten Demak), pada Program Pascasarjana Magister Kenotariatan Universitas Diponegoro, Semarang 2006.

Nur Hidayati, Tinjauan Yuridis Tentang Hak Janda Dalam Pembagian Warisan Menurut Hukum Adat Jawa (Studi Kasus di Pengadilan Negeri Sukoharjo), Skripsi pada Fakultas Hukum Universitas Sebelas Maret, Surakarta, 2008.

Pasnelyza Karani, Tinjauan Ahli Waris Pengganti Dalam Hukum Kewarisan Islam Dan Hukum Kewarisan KUHPerdata, Tesis pada Program Pascasarjana Magister Kenotariatan Universitas Diponegoro, Semarang 2006.

Ratno Lukito, Islamic Law And Adat Ecounter The Experience Of Indonesia, A Thesis submitted to the Faculty of Graduate Studies and Research in partial fulfillment of the requirements for the degree of Master of Arts in Islamic Studies Institute of Islamic Studies McGill University Montreal, Canada, 1997.

\section{Seminar}

Mohd Ridzuan Awang, The Islamic Inheritance Law (Faraid): The Manifestation of Comprehensive Inheritance Management In Islam, working paper was presented at the National Convention of Faraid and Hibah 2008, organised by the Islamic Development Malaysia Department (JAKIM) at the Multipurpose Hall of the Federal Territory Mosque, Kuala Lumpur on 7 August 2008, pg. 10 .

\section{Makalah}

Hartono Soerjopratiknjo. Hukum Waris Testamenter, Seksi Notariat Fakultas Hukum Universitas Gajah Mada, Yogyakarta, 1984.

Nur Mohamad Kasim, Studi Komparatif Waris Menurut Hukum Islam Dan Hukum Adat, Research Paper.

Chatib Rasyid, Azas-Azas Hukum Waris Dalam Islam, Research Paper.

\section{Peraturan Perundang-Undangan}

Undang-Undang Dasar 1945

Kitab Undang-Undang Hukum Perdata

Instuksi Presiden Nomor 1 Tahun 1991 tentang Kompilasi Hukum Islam 